\title{
Delimitation of domains in the external Río de la Plata estuary, involving phytoplanktonic and hydrographic variables
}

\author{
Ana Martínez, Leonardo Ortega
}

\author{
Laboratorio de Oceanografía, Departamento de Biología Poblacional \\ Dirección Nacional de Recursos Acuáticos (DINARA), MGAP \\ Constituyente 1497, Montevideo, Uruguay CP11200 \\ *Corresponding author: anamart30@gmail.com
}

\begin{abstract}
Autumn and spring hydrological (temperature and salinity) and biological (chlorophyll, phaeopigments and phytoplankton species) variables were analysed. Phytoplankton biomass, expressed as chlorophyll a reach a maximum of $6.1 \mu \mathrm{g} \mathrm{L}^{-1}$ in autumn and $22.8 \mu \mathrm{g} \mathrm{L}^{-1}$ during spring. Maxima were found in the frontal zone and marine adjacent area. Four domains were identified through multivariate analysis: Riverine, Estuarine, Frontal and Oceanic; mainly due to salinity and depth in autumn and due to salinity and chlorophyll in spring. The Riverine and Oceanic domains (West and East boundaries) matched in location in both seasons, while in spring an additional domain was discerned in the Canal Oriental (Channel domain). Salinity and chlorophyll concentration increased from the Riverine to the Frontal domain, being positively correlated for salinities 14 , indicating that chlorophyll concentration was modulated mainly by the oceanic influence that improved light availability. While salinity maintains an increasing trend toward the Oceanic domain, phytoplankton biomass decreases. Though in this zone the chlorophyll concentration must be regulated by a combination of light availability and grazing, further investigation is needed.
\end{abstract}

Descriptors: Río de la Plata, chlorophyll, fronts, domains, Uruguayan shelf

\section{RESUMO}

Neste trabalho foram analisadas no Rio da Prata as variáveis hidrológicas (temperatura e salinidade) e biológicas (clorofila, feopigmentos e espécies de fitoplâncton) por ocasião do outono e primavera (Uruguai). A biomassa do fitoplâncton, expressa como teor de clorofila, alcançou um máximo de $6,1 \mu \mathrm{g} \mathrm{\textrm {L } ^ { - 1 }}$ no outono e 22,8 $\mu \mathrm{g} \mathrm{L}^{-1}$ na primavera. Esses máximos foram encontrados na zona frontal e na área marinha adjacente. Por meio de análises multivariadas, foram identificados quatro domínios: Ribeirinho, Estuarino, Frontal e Oceânico, com base na salinidade e profundidade no outono e na salinidade e clorofila na primavera. Em ambas as estações, os domínios Ribeirinho e Estuarino (bordas leste e oeste) estiveram localizados no mesmo local, mas, na primavera, um domínio adicional foi encontrado no Canal Oriental (domínio Canal). Tanto a salinidade quanto a concentração de clorofila aumentou do domínio Ribeirinho para o Frontal, o que se correlacionou de forma positiva com salinidades $\leq 14$, o que sugere que a concentração de clorofila está sendo modulada principalmente pela influência oceânica no sentido de melhorar a disponibilidade de luz. Enquanto a salinidade tende a aumentar no sentido do domínio Oceânico, a biomassa de fitoplâncton diminui. Aparentemente, nessa região a concentração de clorofila estaria sendo regulada pela combinação de disponibilidade de luz e forrageio. Entretanto, novas pesquisas necessitam ser desenvolvidas para dar sustentação a essas hipóteses.

Descritores: Rio da Prata, Clorofila, Frentes, Domínios, Plataforma uruguaia. 


\section{INTRODUCTION}

Twenty percent of marine fish catches comes from coastal zones of intense human activity (PAULY; CHRISTENSEN, 1995) and the Uruguayan coast is no exception. The high biological productivity of the Uruguayan shelf has been associated with its complex hydrography and the presence of strong temperature and salinity gradients (ORTEGA; MARTÍNEZ, 2007). Fronts are zones of high phytoplankton biomass (LE FÈVRE, 1986; LAUBSHER et al. 1993; OLSON et al., 1994; FRONEMAN et al.,1997; SHANKS; MCCULLOCH, 2003) and also of improved production at higher trophic levels (LARGIER, 1993; MANN; LAZIER, 1996). Moreover, frontal zones have mechanisms that promote larval retention (MUNK et al., 2003; SHANKS et al., 2003) and are used as feeding, spawning, nursery and breeding areas by fish, invertebrate populations and pelagic seabirds (BAKUN; PARRISH, 1991; ACHA et al., 2004). Shelf waters are a result of the water masses advected from adjacent zones and modifications due to atmospheric exchange and continental discharge (GUERRERO; PIOLA, 1997), mainly from the Río de la Plata - one of the largest estuarine systems in the world (FRAMIÑAN; BROWN, 1996). When the Río de la Plata reaches open waters, it forms an intense and active salinity and turbidity front whose features and position vary greatly as between seasons and years. The estuary dynamics impact the shelf up to a distance of $400 \mathrm{~km}$ (SIMIONATO et al., 2005).

In coastal nutrient-rich but turbid waters such as those of the Río de la Plata, the phytoplankton growth is limited primarily by light availability (CLOERN, 1987; ALPINE; CLOERN, 1988; CLOERN, 1996). Under such conditions the phytoplankton biomass distribution can be expected to reflect horizontal gradients in those variables (e.g. turbidity, salinity) that modulate light availability (PENNOCK, 1985; CLOERN et al., 1985; CLOERN, 1999). Combined with turbidity, the water column mixing due to the scarce depth could cause the phytoplankton to stay most of the time in darkness, thus experiencing a loss in biomass (COLE et al., 1992). Although several oceanographic research projects have been undertaken in the Río de la Plata (GUERRERO et al., 1997, NAGY et al., 2002, CALLIARI et al., 2005; CARRETO et al., 2008), most of them have analyzed large scale processes involving the whole estuary. Our goal is to differentiate domains by means of hydrological and biological variables involving mesoscale processes, and areas with greater or lesser phytoplankton biomass and different species composition in this part of the estuary and review their biological importance.

\section{STUdy AREA}

The Río de la Plata is a micro-tidal estuary $320 \mathrm{~km}$ long and $230 \mathrm{~km}$ wide at the mouth. It is located between latitudes $34^{\circ} 00^{\prime} \mathrm{S}$ and $36^{\circ} 20^{\prime} \mathrm{S}$ and longitudes $55^{\circ} 00^{\prime} \mathrm{W}$ and $58^{\circ} 30^{\prime} \mathrm{W}$. It drains the second largest basin of South America and its two major tributaries are the Paraná and Uruguay rivers. The resulting outflow is on average 22000 m3s-1 (FRAMIÑAN; BROWN, 1996) showing seasonal variability with its maximum in March-June and September-October and its minimum from December to March (GUERRERO et al., 1997; NAGY et al., 2002). Additional variability on longer time scales is associated with ENSO (El Niño Southern Oscillation), inducing floods (and droughts) during warm (and cold) events respectively (PISCIOTTANO et al., 1994; CAZESBOEZIO et al., 2003). The position of turbidity maximum is highly variable according to tide, river discharge and wind (FRAMIÑAN; BROWN, 1996). Nutrient levels are high along the freshwater areas decreasing seaward and the overall eutrophic condition is moderate (NAGY et al., 2002). The Rio de la Plata can be divided into inner and outer regions (CARP, 1989) based on their morphology and dynamics. The inner, fluvial system is under strong tidal influence and presents high turbidity, having depths of between 1 and $5 \mathrm{~m}$. The outer, less turbid, mixohaline system has depths of between 5 and $25 \mathrm{~m}$ and vertical stratification (FRAMIÑAN et al., 1999; MIANZAN et al., 2001a). This study focused on the outer region of the Río de la Plata and the adjacent marine area between latitudes $34^{\circ} 54^{\prime} \mathrm{S}$ and $35^{\circ} 45^{\prime} \mathrm{S}$ and the 5 and $50 \mathrm{~m}$ isobaths (Fig. 1)

\section{MATERIAL AND METHODS}

\section{SAMPLING AND LABORATORY ANALYSIS}

Two survey cruises were carried out, the first during autumn (17-19 May) and the second in spring (17-19 November) of 2001 onboard the R.V. "Aldebaran". Four transects were sampled in autumn and three in spring (Fig.1), the former comprising 47 oceanographic stations and the latter 36 stations (though maintaining the autumn station numbers); the distance between stations was of approximately $10 \mathrm{~nm}$. At each station, a conductivity, temperature, and depth (CTD) cast (SBE-19) profiled the water column from the surface to the bottom. 


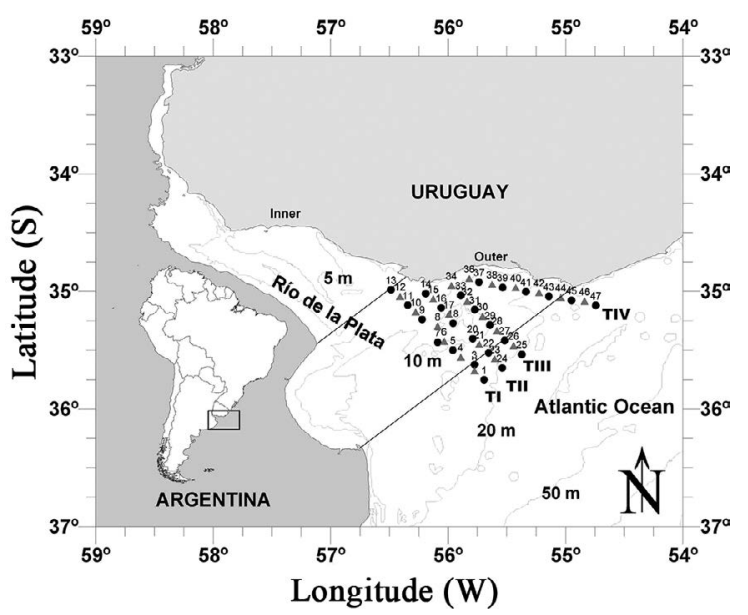

Figure 1. Map of the study area with the position of the surveyed stations; $\bullet$, all parameters; $\mathbf{\nabla}$, only CTD station.

Water samples for biological analyses were taken with Niskin bottles from the surface, 5, 10 and when possible $20 \mathrm{~m}$ depths. Immediately after collection, the water samples were filtered through glass fiber filters (Whatman $\mathrm{GF} / \mathrm{C}, 47 \mathrm{~mm}$ ) to assess total chlorophyll. Filters were stored, dried and frozen for subsequent analysis in the laboratory. Chlorophyll was extracted with 90\% acetone and analyzed with a Shimadzu UV-2101 PC, UV-VIS Scanning spectrophotometer before and after acidification. Chlorophyll $a(\mathrm{Chl} a)$ concentration was calculated according to Jeffrey; HUMPHREY (1975) with correction for phaeopigments (LORENZEN, 1967). To obtain one Chl $a$ value for each station, that would allow the comparison and differentiation of areas with high chlorophyll concentration, we calculated the average $\mathrm{Chl} a$ per cubic meter (mean integrated $\mathrm{Chl} a$ ). The mean integrated Chl $a$ at each station was estimated by graphical integration of the discrete values and then divided by the integration depth. Qualitative phytoplankton samples were taken with a $25 \mu \mathrm{m}$ net and fixed with $4 \%$ buffered formalin. Phytoplankton species were identified using an optical microscope Leitz DIAPLAN. Diatoms were cleaned according to the Hasle and Fryxell method (FERRARIO et al., 1995) just for identification purposes.

\section{DATA ANALYSIS}

K-means clustering (MACQUEEN, 1967) and nonmetric Multidimensional Scaling (MDS) analysis, using a squared Euclidean distance matrix with raw data, were employed in order to group stations with similar characteristics and to define hydrographic domains. Variables involved were: depth, mean salinity (in the water column), mean temperature (in the water column), mean integrated Chl $a$ and the mean Chla/phaeopigments index. Also a K-means and an MDS with the phytoplankton species presence/absence categorized (0-4) data matrix were done. A nonparametric Spearman rank correlation was performed with data (mean temperature, salinity and Chla/phaeopigments values and mean integrated $\mathrm{Chl} a$ ) from both seasons, divided into two sets in relation to the surface salinity frontal zone, i.e. salinity (S) $£ 14$ and S $>14$. Stratification of the water column was calculated, dividing the difference between bottom and surface salinities by depth.

\section{RESULTS}

\section{TEMPERATURE}

\section{Autumn}

A cold water patch $\left(14-14.5^{\circ} \mathrm{C}\right)$ with a major diameter of ca. $80 \mathrm{~km}$ occupied great part of transects (T) I, II and III. The analysis of the vertical distribution of temperature on the transects (Fig. 2A) shows the prevalence of cold waters at the surface $\left(13.5-16^{\circ} \mathrm{C}\right)$ over the study area, recording relatively lower temperatures on TI and TII $\left(13.5-14.5^{\circ} \mathrm{C}\right)$ as well as the drop of the $14.5^{\circ} \mathrm{C}$ isotherm, confirming the existence of that cold water patch, reaching a maximum depth of $\sim 10 \mathrm{~m}$. Temperature tended to increase with depth along each transect (Fig. 2A) and also from TI to TIV (Mean \pm SD; $14.58 \pm 0.61,14.89 \pm$ $0.61,15.42 \pm 0.45,16.01 \pm 0.28^{\circ} \mathrm{C}$ TI, TII, TIII, and TIV respectively). This pattern was also observed on TI and TII when considering the distance from the coast; TIII and TIV recorded a higher temperature along the whole transect. Particularly on TIII did the $15.6^{\circ} \mathrm{C}$ isotherm located near the bottom at the outermost stations reach the surface in the middle of the transect; waters of low temperature $\left(14.6^{\circ} \mathrm{C}\right)$ were observed offshore, contrasting with those observed at coastal stations $\left(15.4-15.6^{\circ} \mathrm{C}\right)$. A deepening of the isotherms flanked by waters at a higher temperature $\left(16^{\circ} \mathrm{C}\right)$ was recorded in the middle of TIV.

\section{SPRING}

The transects recorded a decrease of temperature with depth and distance from the coast (Fig. 2B). Temperature on TI ranged between 20 and $18.5^{\circ} \mathrm{C}$ at the surface, recording lower temperatures $\left(17^{\circ} \mathrm{C}\right)$ at the bottom at outer stations. TIII recorded relatively lower temperatures than TI, surface values ranging between 19.5 and $18^{\circ} \mathrm{C}$ and $17^{\circ} \mathrm{C}$ deep offshore. Finally, TIV recorded high vertical 

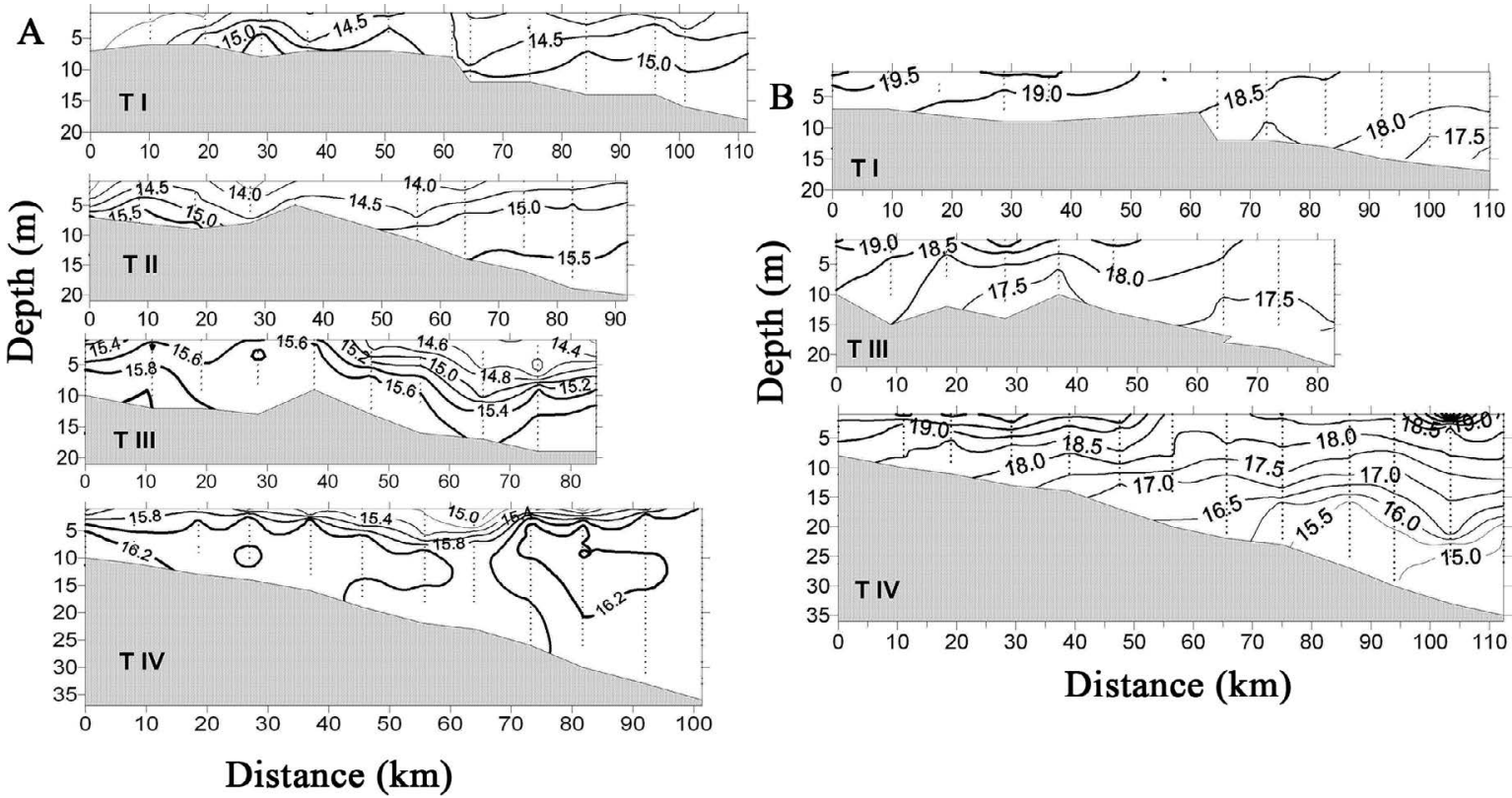

Figure 2. Temperature in ${ }^{\circ} \mathrm{C}$ vertical sections during autumn (A) and spring (B), small dots display the surveyed depth at each station.

gradients varying from $\sim 20^{\circ} \mathrm{C}$ at the surface at coastal stations, and $15^{\circ} \mathrm{C}$ at the bottom at deeper stations. Also, mean temperature decreased from TI to TIV (Mean \pm SD; $\left.18.38 \pm 0.64,17.95 \pm 0.53,17.39 \pm 1.36^{\circ} \mathrm{C}\right)$.

\section{SALINITY}

\section{AUTUMN}

The vertical distribution of salinity showed a clear increase with depth (Fig. 3A) and distance from the coast on TI and TII, which recorded the lowest values at the coastal stations $(S<4)$. Low salinity values were observed on TIII (19) offshore and TIV (21) at middle stations (approximately $60-70 \mathrm{~km}$ from the origin). Similarly to temperature, mean values of salinity increase from TI to TIV (Mean \pm SD; $18.47 \pm$ 9.93, $21.94 \pm 8.66,26.42 \pm$ $4.47,30.47 \pm 3.35$ on TI, TII, TIII and TIV, respectively). The highest surface values were recorded at the coastal stations of TIII and TIV $(24-26)$.

\section{SPRING}

Unlike temperature, salinity increased from TI to TIV (Mean \pm SD; $20.05 \pm 8.08,25.66 \pm 4.03,27.65 \pm$ 3.91). TI recorded the lowest salinity, reaching values < 2 at coastal stations, increasing gradually seawards (Fig. 3B). A well-defined frontal zone could be discerned in the middle section, where salinity varied from 10 to 20 in approximately $20 \mathrm{~km}$ (i.e. a salinity gradient $\sim 0.5 \mathrm{~km}-1$ ).
TIII showed values higher than TI, registering 14 at the surface near the coast and 26 at outer stations, reaching 30 in bottom waters. A high vertical stratification associated with the coastal zone was also recorded. As has been described for TI, a continuous offshore increase in salinity was observed. Finally, TIV recorded the highest mean value, attaining 15 near the coast, 25 at the surface and 32 at the bottom at the offshore extreme; a strong vertical stratification also being recorded at depths $<15 \mathrm{~m}$ (Fig. 3B).

\section{Pigments}

\section{AUTUMN}

TI recorded the lowest chlorophyll mean value $\left(0.41 \pm 0.74 \mathrm{mg} \mathrm{L}^{-1}\right)$, and the concentration increased with distance from the coast, reaching $2.85 \mathrm{mg} \mathrm{L}^{-1}$ at the surface at offshore stations (Fig. 4A). TII recorded a similar pattern but the mean value was higher $(0.82 \pm 0.95$ $\left.\mathrm{mg} \mathrm{L}^{-1}\right)$, and, as in TI, the maximum $\left(2.93 \mathrm{mg} \mathrm{L}^{-1}\right)$ was at the surface at offshore stations. TIII followed the same increasing trend in mean value $\left(1.43 \pm 1.47 \mathrm{mg} \mathrm{L}^{-1}\right)$ and distribution, i.e. maximum discrete value was registered far from the coast $\left(6.14 \mathrm{mg} \mathrm{L}^{-1}\right)$. Finally, TIV recorded a lower mean value than TII and TIII $\left(0.65 \pm 0.52 \mathrm{mg} \mathrm{L}^{-1}\right)$ and the maximum $\left(1.86 \mathrm{mg} \mathrm{L}^{-1}\right)$ was located in the middle of the transect associated with cold surface water (Fig.4A). The phaeopigments follow the same pattern, increasing from TI to TIII, reaching the maximum mean value $(3.8 \pm$ 

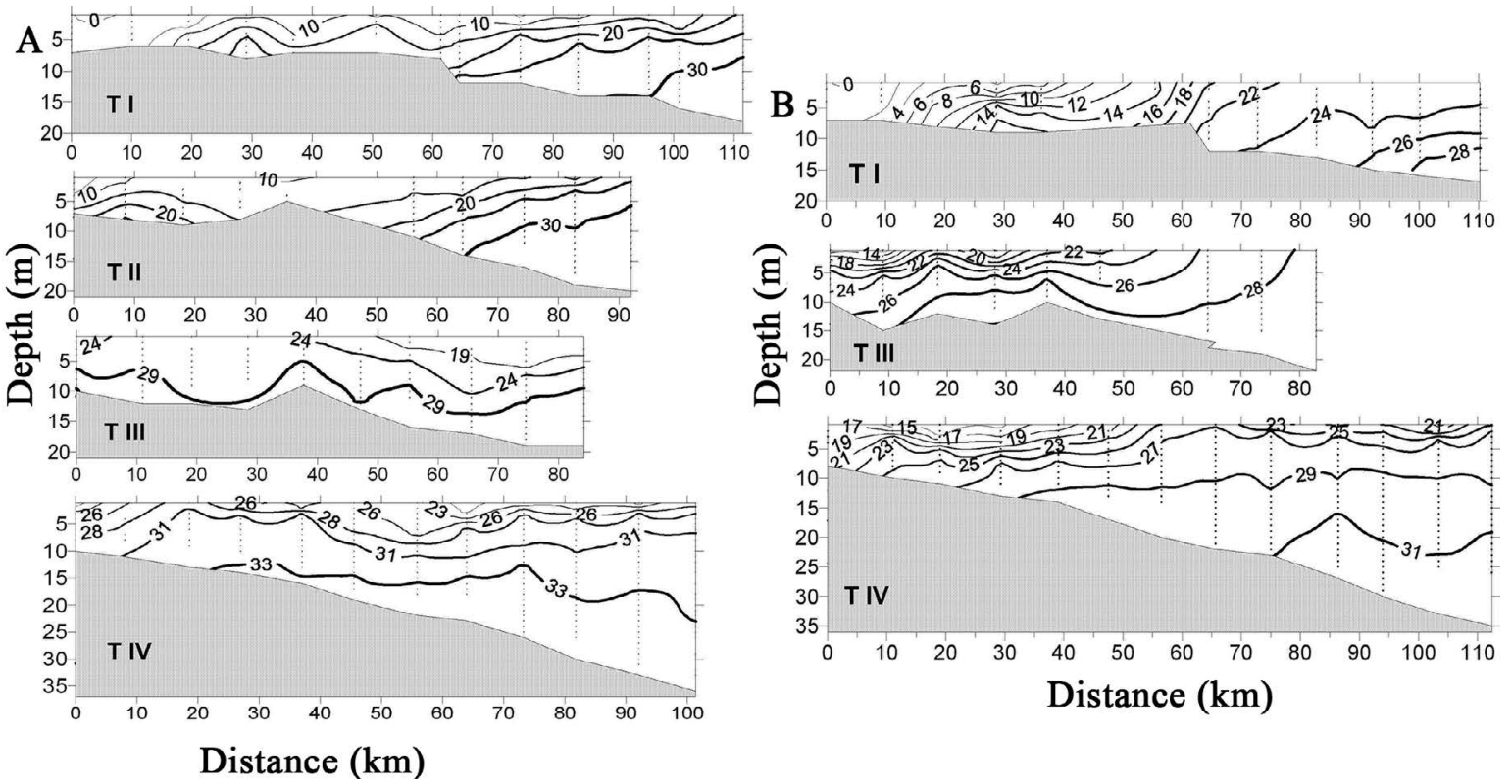

Figure 3. Salinity vertical sections during autumn (A) and spring (B), small dots display the surveyed depth at each station.

4.0 $\mathrm{mg} \mathrm{L}^{-1}$ ) on TIII, and then decreasing on TIV, although the maximum discrete value $\left(12 \mathrm{mg} \mathrm{L}^{-1}\right)$ was found on TIV in subsurface waters (not shown). It is worthy of mention that all the maximum $\mathrm{Chl} a$ values were associated mainly with high abundance of Akashiwo sanguinea. Also the $\mathrm{Chl}$ $a /$ phaeopigments index showed an increasing trend from TI to TIV (Mean \pm SD; $0.2 \pm 0.2,0.46 \pm 0.39,0.49 \pm 0.31$ and $1.51 \pm 4.5$ for TI, TII, TIII and TIV, respectively), the vertical pattern coinciding with that of the phaeopigments. The maximum (20) was found at station 45 (TIV). Mean integrated Chl $a$ values ranged between 0 and $1.74 \mathrm{mg} \mathrm{L1}$ and the maximum values were found on the marine side of the surface salinity front (S 14 - 18) (Fig. 5A).

\section{SPRING}

Mean chlorophyll a concentration showed an increasing trend from TI to TIV (Mean \pm SD; $1.15 \pm$ $\left.0.96,1.68 \pm 1.41,6.23 \pm 6.33 \mathrm{mg} \mathrm{L}^{-1}\right)$. On TI the lowest concentration of $\mathrm{Chl} a$ was found adjacent to the coast, the maximum $\left(3 \mu \mathrm{g} \mathrm{L}^{-1}\right)$ being associated with the frontal zone described before for salinity (Fig. 4B). TIII recorded higher values, reaching a maximum of $4 \mu \mathrm{g} \mathrm{L}^{-1}$ at the surface near the coast. A relatively high concentration was also recorded in the middle of the transect, decreasing in areas with greater oceanic influence. The highest concentration of Chl $a$ was found on TIV, reaching a surface maximum of $22.8 \mu \mathrm{g} \mathrm{L}^{-1}$ near the coast (station 37), also associated with the maximum gradient described for salinity. Values recorded at this station were high throughout the water column. The maximum phaeopigments value $\left(19 \mu \mathrm{g} \mathrm{L}^{-1}\right)$ was registered at the outer stations of TIV (not shown) and the mean values of each transect were similar (Mean $\pm \mathrm{SD} ; 4.0 \pm 3.2,3.6 \pm 2.9$ and $5.7 \pm 4.7 \mu \mathrm{g} \mathrm{L}^{-1}$, for TI, TIII and TIV, respectively). The $\mathrm{Chl} a$ /phaeopigments index showed the same pattern as that at station 45 (TIV). Mean values showed an increasing trend from TI to TIV (Mean $\pm \mathrm{SD} ; 0.53 \pm 0.50,0.58 \pm 0.38$ and $2.40 \pm 4.42$ for TI, TIII and TIV, respectively). Mean integrated $\mathrm{Chl} a$ values ranged from 0 to $17.25 \mu \mathrm{g} \mathrm{L} \mathrm{L}^{-1}$ and the maximum ones were in the salinity frontal region (S 14 - 18) near the coast and adjacent marine area (Fig. 5B).

\section{DOMAINS}

Four domains were defined in autumn through the K-means clustering and MDS analysis (Fig. 6A) (stress = 0.02 ) and five in spring (Fig. 6B) (stress $=0.02$ ). Salinity and depth were the main variables defining the domains during autumn $(\mathrm{F}=66.28 p<0.0001$ and $\mathrm{F}=31.22 p$ $<0.0001$, respectively) while salinity and chlorophyll defined them in spring $(\mathrm{F}=30.35 p<0.0001$ and $\mathrm{F}=$ $26.65 p<0.0001$, respectively). K-means and MDS analysis of the phytoplankton species defined analogous domains (not shown). The main discriminating species in autumn were Aulacoseira granulata $(\mathrm{F}=142.9 p$ $<0.0001)$, Pediastrum duplex $(\mathrm{F}=74.5 p<0.0001)$, Akashiwo sanguinea $(\mathrm{F}=29.7 p<0.0001)$ and Proboscia 


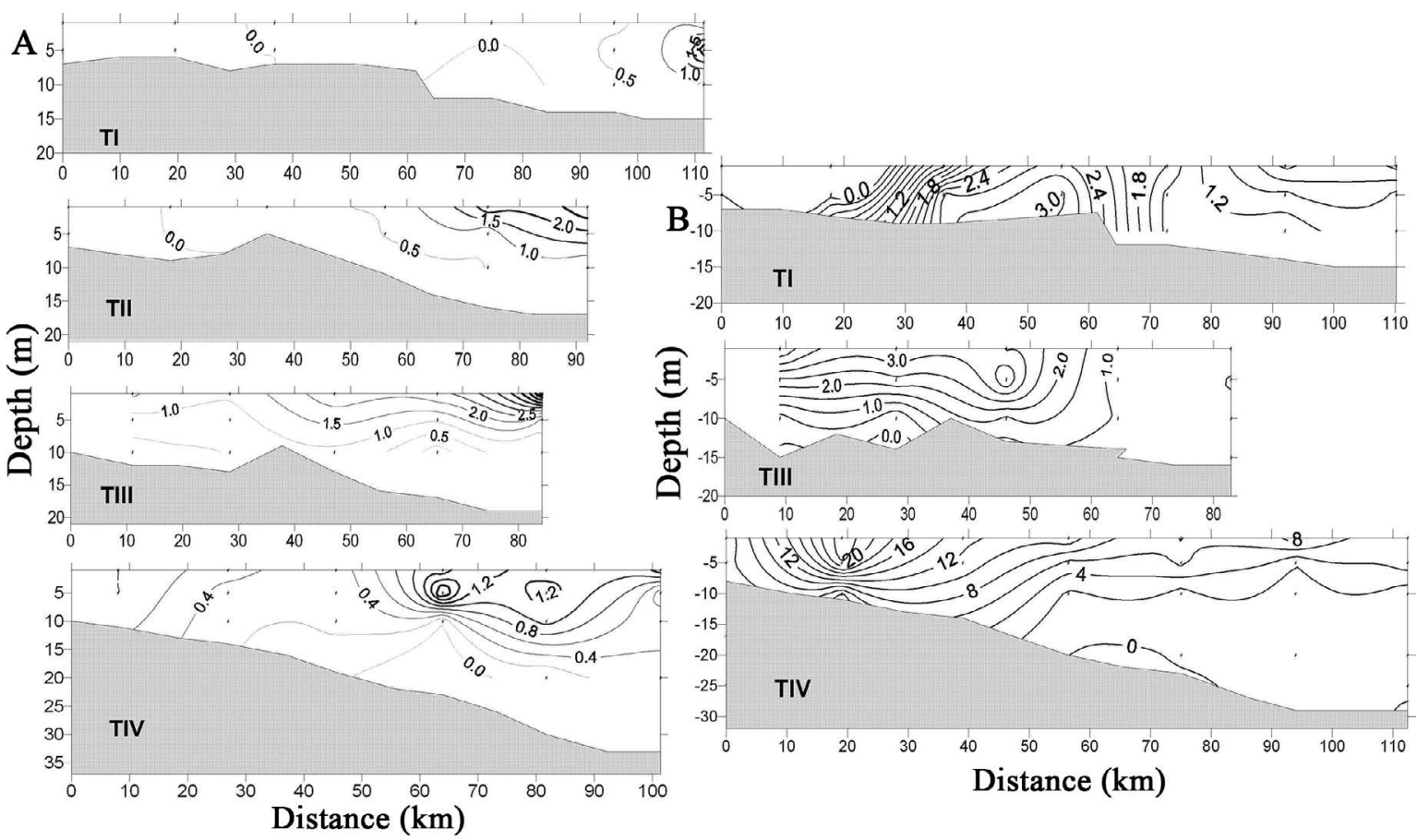

Figure 4. Vertical distribution of chlorophyll a $\left(\mu \mathrm{g} \mathrm{L}^{-1}\right)$ during autumn (A) and spring (B).

alata $(\mathrm{F}=20.5 p<0.0001)$. In spring the main defining species were Dinophysis caudata $(\mathrm{F}=100.7 p<0.0001)$, Goniodoma polyedricum $(\mathrm{F}=50.8 p<0.0001)$, Proboscia alata $(\mathrm{F}=28.4 p<0.0001)$, Aulacoseira granulata $(\mathrm{F}$ $=26.7 p<0.0001)$ and Oxytoxum sceptrum $(\mathrm{F}=14.8 p$ $<0.0001)$. The geographical location of the domains is comparable in both seasons. One of them is a freshwater area (Riverine domain) which corresponds to station 13 in both seasons (Fig. 7). This area showed freshwater salinity (Mean $\pm \mathrm{SD} ; 0.073 \pm 0.00$ and $0.078 \pm 0.0007$ in autumn and spring, respectively) as well as extremely low $\mathrm{Chl} a$ concentration, the phaeopigments prevailing (Mean $\pm \mathrm{SD} ; 0.47 \pm 0.66$ and $9.34 \pm 2.60 \mu \mathrm{g} \mathrm{L} \mathrm{L}^{-1}$ in autumn and spring, respectively). The phytoplankton community was represented by freshwater species, mainly Aulacoseira spp, Surirella spp, Closterium spp, Pediastrum spp and Scenedesmus spp. The other area that matched exactly in both seasons was the marine border (Oceanic domain) corresponding to stations 45 and 47 (Fig. 7). It was characterized by relatively high salinity (Mean $\pm \mathrm{SD}$; $31.25 \pm 2.78$ and $29.5 \pm 1.96$ for autumn and spring, respectively) and intermediate values of Chl $a$ (Mean $\pm \mathrm{SD}$; $0.73 \pm 0.53$ and $3.12 \pm 2.83 \mu \mathrm{g} \mathrm{L}{ }^{-1}$ for autumn and spring, respectively). The highest chlorophyll/phaeopigments index was registered in this domain. The representative species were from marine warm waters, Proboscia alata,
Proboscia indica, Eucampia zodiacus and Neoceratium pentagonum. An estuarine area (Estuarine domain) was outlined, involving a broader area in autumn than in spring (Fig. 7), showing relatively low salinity values (Mean \pm SD; $12.58 \pm 6.15$ and $12.16 \pm 4.70$ for autumn and spring, respectively) and low Chl $a$ values (Mean \pm $\mathrm{SD} ; 0.21 \pm 0.21$ and $2.48 \pm 2.00 \mu \mathrm{g} \mathrm{L}^{-1}$ for autumn and spring respectively). This domain did not show particular species, the species found were shared with other domains; those that showed higher abundance being Odontella aurita, Coscinodiscus jonesianus and Neoceratium furca. Lastly, the fourth area corresponds to the frontal region and adjacent marine zone (Frontal domain), whose geographical location also varied between seasons (Fig. 7). This area showed relatively high salinity (Mean $\pm \mathrm{SD}$; $27.44 \pm 4.76$ and $26.16 \pm 3.47$ for autumn and spring, respectively) and high $\mathrm{Chl}$ a (Mean $\pm \mathrm{SD} ; 1.06 \pm 1.15$ and $3.39 \pm 4.75 \mu \mathrm{g} .1^{-1}$ for autumn and spring, respectively). This domain presented typically estuarine and marine species such as Coscinodiscus wailesii and Triceratium favus; Akashiwo sanguinea, Alexandrium fraterculus, Protoceratium sp. and Neoceratium candelabrum were also found exclusively in this domain. An additional area located in the Canal Oriental (Channel domain) (Fig. 7B) with intermediate values of salinity $(22.68 \pm 5.00)$ and high Chl a concentration $\left(14.56 \pm 8.17 \mu \mathrm{g} \mathrm{L}^{-1}\right)$ was delimited in 


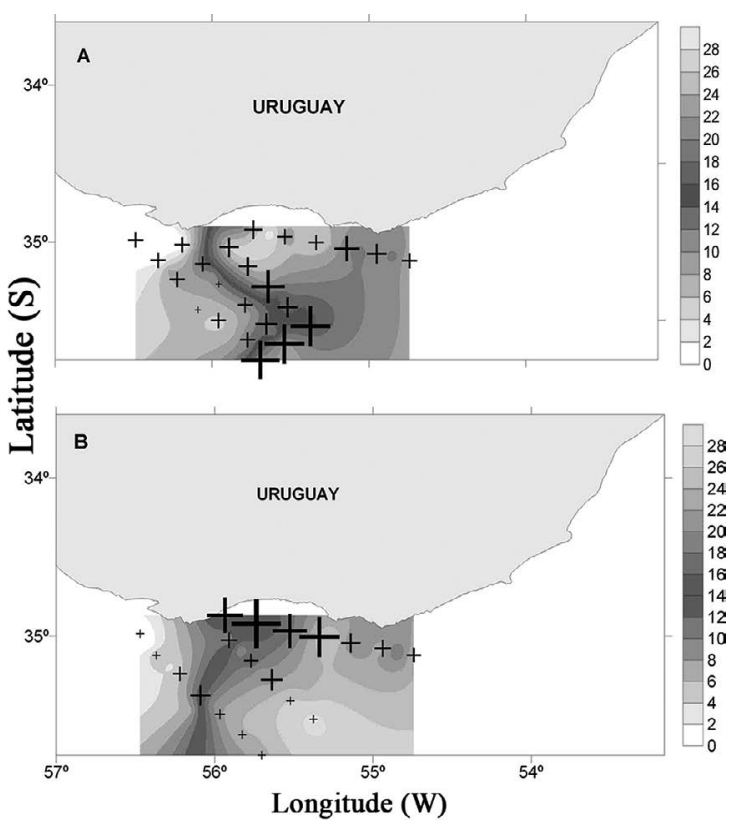

Figure 5. Mean integrated chlorophyll a $\left(\mu g \mathrm{~L}^{-1}\right)$ (crosses) and surface salinity (colour contours) during autumn (A) and spring (B). The point size is proportional to the chlorophyll concentration $\left(0\right.$ to $1.74 \mu \mathrm{g} \mathrm{L}^{-1}$ in autumn and 0 to $5.66 \mu \mathrm{g} \mathrm{L}^{-1}$.in spring).
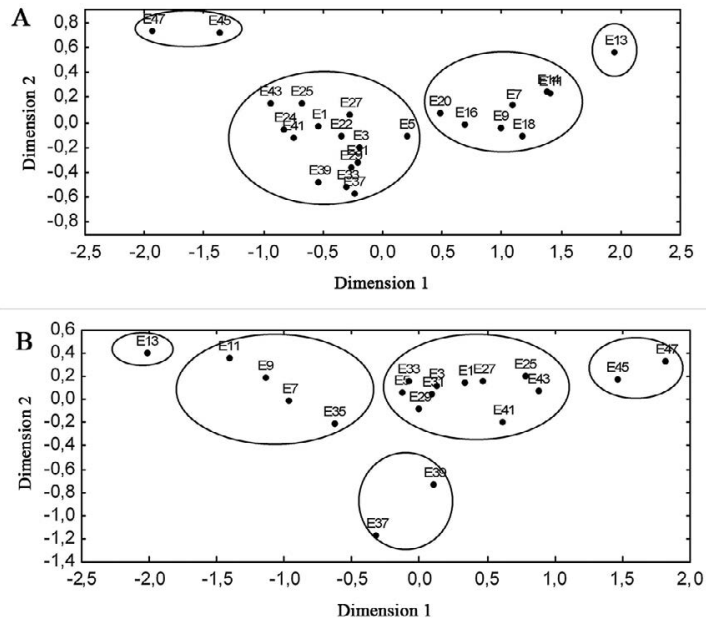

Figure 6. Two dimensions multidimensional scaling scatter plot for autumn (A) and spring (B). Circles indicate the domains determined.

spring next to the coast. This domain was characterized by high abundance of Oxytoxum spp.

The nonparametric Spearman's rank correlation showed significant correlation between mean integrated Chl $a$ and salinity as well as between the Chl $a$ / phaeopigments index and salinity for $\mathrm{S}<=14(\mathrm{R}=0.71$, $p=0.002, \mathrm{n}=16$ and $\mathrm{R}=0.66, p=0.005, \mathrm{n}=16$ for salinity $v s$. mean integrated $\mathrm{Chl} a$ and salinity $v s$. Chl $a$ /

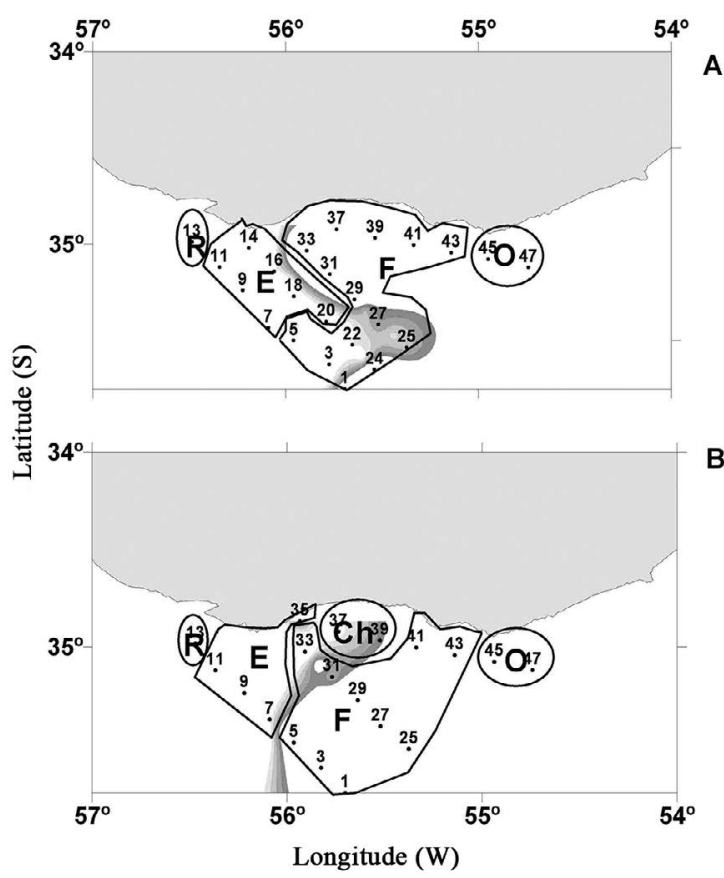

Figure 7. Delimited domains from the multidimensional scaling analysis and position of the surface salinity front for autumn (A) and spring (B). R: Riverine domain; E: Estuarine domain; F: Frontal domain; O: Oceanic domain and $\mathrm{Ch}$ : Channel domain.

phaeopigments, respectively). However, for $\mathrm{S}>14$ no significant correlation was found between salinity and the $\mathrm{Chl} a$ /phaeopigments index $(\mathrm{R}=-0.007, p=0.97, \mathrm{n}=27)$ and a negative correlation was registered between salinity and mean integrated Chl $a(\mathrm{R}=-0.40, p=0.04, \mathrm{n}=27)$.

\section{DISCUSSION}

During autumn the progressive increase of temperature from TI to TIV and seaward, confirms the influence of warm waters over the shelf, particularly eastward, contrasting with the cold estuarine waters. This influence was evident at the coastal stations of TII and TIII and the entire TIV; however, since our sampling occurred in late autumn, the onset of a northward transport of cold diluted Subantartic Shelf Water could be expected. The colder oceanic water species found in the south of the study area corroborate the intrusion of Subantartic Water (SAW). A northward transport of cold shelf waters south of Bahía de Samborombón (Argentina) had previously been reported (LASTA et al., 1996; FRAMIÑAN et al., 1999; SIMIONATO et al., 2004) in accordance with the distribution of surface isotherms in that area during autumn. Vertical sections displayed low vertical stratification in temperature during autumn; thermal inversion indicating the influence of warmer shelf waters on 
bottom layers and less dense cold estuarine waters on surface layers. Thermal inversions are a common feature during the cold season when haline-stratification determines that the surface fresh water layer loses heat rapidly. GUERRERO et al. (1997) also found a negative sign in the stratification in the fall-winter period due to cooler riverine waters lying over warmer shelf waters.

The estuarine discharge plume was wider during autumn as was noticed in the horizontal surface salinity distribution for both seasons, showing a northeastward discharge along the Uruguayan coast as has previously been stated by GUERRERO et al. (1997) and SIMIONATO et al. (2004).

During late spring, the weakening of the cold water influence was observed concurrently with an enhanced transport of warm oceanic waters from the NE. The main penetration of warm waters seems to be by the deep channel (Canal Oriental) since warm water phytoplankton species (e.g Goniodoma polyedricum) were found in that zone. The coastal penetration of warm oceanic water is generally associated with a lower river discharge that allows the intrusion of oceanic waters toward the coast, as well as the associated biota (MIANZAN et al., 2001b; PIMIENTA et al., 2005; DEMICHELI et al., 2006; ORTEGA; MARTÍNEZ, 2007). The estuarine waters were also warmer and the region showed a higher temperature than in autumn. Spring oceanic shelf waters recorded lower temperatures than the estuarine ones, as stated in GUERRERO et al. (1997).

Chlorophyll values were in the same range as in other turbid estuaries (ALPINE; CLOERN, 1988) and in previous research in the Río de la Plata (NAGY et al., 2002; CARRETO et al., 2003; CALLIARI et al., 2005; CARRETO et al., 2008). Higher values were found in spring in accordance with the annual cycle proposed for other temperate water bodies (PARSONS et al., 1977). Moreover, in autumn the greater Río de la Plata discharge (GUERRERO et al., 1997) could increase the concentration of suspended solids and thus diminish light availability, causing even lower productivity. Regarding the horizontal distribution, higher values were found in the frontal zone and the adjacent marine zone, as expected, in accordance with other authors (LARGIER, 1993; MANN; LAZIER, 1996; ACHA et al., 2008). In this zone the nutrient concentration is still high and the improved light environment, due to a minor concentration of suspended solids and vertical stratification, enhances productivity (PENNOCK, 1985; CLOERN, 1987).

The surface thermohaline front divided the sampling area in two main regions. During autumn a cold and fresh one located in the $\mathrm{W}$ and a warmer and salty one in the $\mathrm{E}$, while in spring the regions were warm and fresh in the W and relatively colder and salty in the $\mathrm{E}$.

The delimited domains agree with these two main areas divided by the thermohaline front, i.e. the Riverine and Estuarine domains in the $\mathrm{W}$; and the Frontal, Oceanic and Channel domains in the E. The Riverine domain recorded extremely low values of $\mathrm{Chl} a$ in both seasons, confirming the findings of ACHA et al. (2008); due to the unfavorable conditions for phytoplankton development related to poor light availability, since it is located within the salt intrusion limit (turbidity maximum). Further, these low Chl $a$ values may be a result of the low volume filtered that determined an extract beneath the limit of detection of the technique. The interference with chlorophyll $b$ as a result of the presence of chlorophytes (e.g. Pediastrum spp and Scenedesmus spp) could also bias the measurement, reducing chlorophyll $a$ and increasing phaeopigments (MANTOURA et al., 1997). The Estuarine domain was characterized by higher phytoplankton biomass than the Riverine, probably due to an improvement in light availability and still high enough nutrient concentration. The Frontal domain (frontal region and marine adjacent zone) recorded the highest phytoplankton biomass, as stated above. Therefore, according to our results, the phytoplankton biomass distribution reflected the horizontal gradient in light availability, confirming other authors' results (PENNOCK, 1985; CLOERN et al., 1985; CLOERN, 1999). Finally, the Oceanic domain showed the great influence of marine shelf waters and relatively high phytoplankton biomass. This Oceanic domain recorded the highest Chl- $a$ /phaeopigments index supporting local production. During spring, the Channel domain, located near the coast, differs from the other zones because of its higher phytoplankton biomass. Under low river discharge, plus an important marine shelf water intrusion through the Canal Oriental, an algal bloom could develop; reaching in our case a maximum of $22.8 \mu \mathrm{g}$ $\mathrm{L}^{-1}$ of $\mathrm{Chl} a$, in agreement with other studies undertaken in the zone (NAGY et al., 2002; CALLIARI et al., 2005) and in other channels of the world (CLOERN et al., 1985). Even in autumn this domain was not differentiated; this area recorded distinct phytoplankton species such as Oxytoxum scolopax, Goniodoma polyedricum and Cerataulina pelagica.

Under calm conditions river discharge and tide determine the amount of suspended particulate matter, light availability and the location of the frontal zone. The former modulates the quality of the organic matter and stratification, resulting 
in a horizontal gradient that structures the phytoplankton biomass and community. Also it accounted for a significant proportion of the observed variability of Chl $a$ in the Riverine and Estuarine domains, since in general terms the haline intrusion is linked to a strengthening of vertical stratification and optical climate. This agrees with results obtained by NAGY et al. (1987), who obtained a negative exponential fit between transparency and salinity during calm periods, directly related to the amount of suspended particulate matter. This positive trend changes beyond the frontal zone where the salinity increment is not associated with an increase in phytoplankton biomass. NAGY et al. (2002) described a strong nutrient removal within the salinity range 0.2 and 18 ; lower nutrient concentrations could, therefore, be expected for salinities greater than 18. Because of the higher biomass found in the frontal and adjacent marine zone the hypothesized lower nutrient concentration might be a result of the phytoplankton uptake. When the mixing between the river and ocean water begins, suspended matter settles rapidly and the resulting water is transparent enough to increase photosynthesis. As a result, high productivity has been observed, which depletes dissolved nutrients (EDMOND et al., 1981). Because of the nutrient depletion the biomass diminishes toward more oceanic and oligotrophic regions (i.e. salinities $>18$ ). Other physical processes could also play an important role (e.g. the pycnocline depth, the ratio mixed/photic depth, lower stratification) since these areas generally involve greater depths. According to PENNOCK (1985) the freshwater and mid-estuarine biomass maxima may be correctly predicted using a steady-state light-limitation model. In contrast, chlorophyll concentrations in the lower estuary are not correctly modeled, despite minimum turbidity, and non-nutrient limiting conditions. These chlorophyll concentrations appear to be regulated by a combination of light availability and grazing (PENNOCK, 1985).

In brief: sharp surface salinity gradients characterized the study area; the surface salinity front divided the whole study area in two main regions. One of them comprised the Riverine and Estuarine domains and the other involved the Frontal and Oceanic domains, as well as the Channel domain in spring.

The combination of hydrographic, phytoplanktonic and topographic parameters proved to be useful in the discrimination of the domains, delimiting regions not only by the hydrographic characteristics but also by the phytoplankton biomass and species. Chlorophyll $a$ maxima were associated with the frontal zone in both seasons.

\section{ACKNOWLEDGMENTS}

This work was partly supported by contract PDT $\mathrm{S} / \mathrm{C} / \mathrm{OP} / 36 / 10$ from DINACYT, Uruguay. We gratefully acknowledge Carmen Mesones for her invaluable collaboration during fieldwork. We also wish to thanks two anonymous referees for their critical comments improving the final manuscript and to COLACMAR for the opportunity to do it.

\section{REFERENCES}

ACHA, E. M.; MIANZAN, H. W.; GUERRERO, R. A.; FAVERO, M.; BAVA, J. Marine fronts at the continental shelves of austral South America: physical and ecological processes. J. Mar. Syst., v. 44, n. 1/2, p. 83-105, 2004.

ACHA, M.; MIANZAN, H.; GUERRERO, R.; CARRETO, J.; GIBERTO, D.; MONTOYA, N.; CARIGNAN, M. Carigran. An overview of physical and ecological processes in the Río de la Plata Estuary. Cont. Shelf. Res., v. 28, p. 1579-1588, 2008.

ALPINE, A. E.; CLOERN; J. E. Phytoplankton growth rates in a light-limited environment, San Francisco Bay. Mar. Ecol. Prog. Ser., v. 44, p. 167-173, 1988.

BAKUN, A.; PARRISH, R. H. Comparative studies of coastal pelagic fish reproductive habitats: the anchovy (Engraulis anchoita) of the southwestern Atlantic. ICES J. Mar. Sci., v. 48, n. 3, p. 343-361, 1991.

CALLIARI, D.; GÓMEZ, M.; GÓMEZ, N. Biomass and composition of the phytoplankton in the Río de la Plata: large-scale distribution and relationship with environmental variables during a spring cruise. Cont. Shelf. Res., v. 25, n. 2, p. 197-210, 2005.

CARP (Comisión Administradora del Río de la Plata), 1989. Estudio para la evaluación de la contaminación en el Río de la Plata. Montevideo-Buenos Aires: Comisión Administradora del Río de la Plata. Informe de Avance, 1989. 422 p.

CARRETO, J. I.; MONTOYA, N. G.; BENAVIDES, H. R.; GUERRERO, R. A.; CARIGNAN, M. O. Characterization of spring phytoplankton communities in the Río de la Plata maritime front using pigment signatures and cell microscopy. Mar. Biol., v. 143, n. 5, p. 1013-1027, 2003.

CARRETO, J. I.; MONTOYA, N.; AKSELMAN, R.; CARIGNAN, M. O.; SILVA, R. I.; CUCCHI COLLEONI, A. D. Cucchi Colleoni. Algal pigment patterns and phytoplankton assemblages in different water masses of the Río de la Plata maritime front. Cont. Shelf Res., v. 28, p. 1589-1606, 2008.

CAZES, G.; ROBERTSON, A. W.; MECHOSO, C. R. Seasonal dependence of ENSO teleconnections over South America and relationships with precipitation in Uruguay. J. Clim., v. 16, n. 8, p. 1159-1176, 2003.

CLOERN, J. E.; COLE, B. E.; RAYMOND, L.; WONG, J.; ALPINE, A. E. Temporal dynamics of estuarine phytoplankton: A case study of San Francisco Bay. Hydrobiología, v. 129, n. 1, p. 153-176, 1985.

CLOERN, J. E. Turbidity as a control on phytoplankton biomass and productivity in estuaries. Cont. Shelf Res., v. 7, n. 11/12, p. 1367-1381, 1987.

CLOERN, J. E. Phytoplankton bloom dynamics in coastal ecosystems: A review with some general lessons from sustained investigation of San Francisco Bay, California. Rev. Geophys., v. 34, n. 2, p. 127-168, 1996. 
CLOERN, J. E. The relative importance of light and nutrient limitation of phytoplankton growth: a simple index of coastal ecosystem sensitivity to nutrient enrichment. Aquat. Ecol., v. 33, p. 3-16, 1999

COLE, J. J.; CARACO, N. F.; PEIERLS, B. L. Can phytoplankton maintain a positive carbon balance in a turbid, freshwater, tidal estuary? Limnol. Oceanogr., v. 37, n. 8, p. 1608-1617, 1992.

EDMOND, J. M., BOYLE, E. A.; GRANT, B.; STALLARD, R. F. The chemical mass balance in the Amazon plume I: The nutrients. Deep-Sea. Res., v. 28, n. 11, p. 1339-1374, 1981.

DEMICHELI, M., MARTÍNEZ, A.; ORTEGA, L.; SCARABINO, F.; MAYTÍA, S.; DEMICHELI, A. Mass stranding of Argonauta nodosa Lightfoot, 1786 (Cephalopoda, Argonautidae) along the Uruguayan coast (Southwestern Atlantic). Rev. Biol. Mar. Oceanogr., v. 41, n. 2, p. 147-153, 2006.

FERRARIO, E. M., SAR, E. A.; SALA, S. E. Metodología básica para el estudio del fitoplancton con especial referencia a las diatomeas. In: ALVEAL, K., FERRARIO, E. M., OLIVEIRA, E., SAR, E. (Eds.). Manual de Métodos Ficológicos. Concepción: Universidade de Concepción. 1995. p. 1-19.

FRAMIÑAN, M. B.; BROWN, O. B. Study of the Río de la Plata turbidity front, Part I: Spatial and temporal distribution. Cont. Shelf Res., v. 16, n. 10, p. 1259-1282, 1996.

FRAMIÑAN, M. B., ETALA, M. P.; ACHA, E. M.; GUERRERO, R. A.; LASTA, C. A.; BROWN, O. B. Physical characteristics and processes of the Río de la Plata estuary. In: PERILLO, G. M. E., PICCOLO, M. C., PINO-QUIVIRA, M. (Eds.), Estuaries of South America. Their Geomorphology and Dynamics. Berlin: Springer, 1999. p. 161-194.

FRONEMAN, P.W., PERISSINOTTO, R.; PAKHOMOV, E. A. Biogeographical structure of the microphytoplankton assemblages in the region of the Subtropical Convergence and across a warm-core eddy during austral winter. J. Plankton. Res., v. 19, n. 4, p. 519-531, 1997.

GUERRERO, R. A., PIOLA, A. R. Masas de agua en la plataforma continental. In: BOSCHI, E. E. ed. El Mar Argentino y sus recursos pesqueros. Antecedentes históricos de las exploraciones en el mar y las características ambientales. Mar del Plata: Instituto de Investigación y Desarrollo Pesquero, 1997. p. 107-118.

GUERRERO, R. A., ACHA, E. M.; FRAMIÑAN, M. B.; LASTA, C. A. Physical Oceanography of the Río de la Plata estuary, Argentina. Cont. Shelf Res., v. 17, n. 7, p. 27-742, 1997.

JEFFREY, S.W., HUMPHREY, G. F. New spectrophotometric equations for determining chlorophylls $\mathrm{a}, \mathrm{b}, \mathrm{c} 1+\mathrm{c} 2$ in higher plants, algae and natural phytoplankton. Biochem. Physiol. Pflanzen. Bd., v. 167, p. 191-194, 1975.

LARGIER, J. L. Estuarine fronts: how important are they? Estuaries, v. 16, n. 1, p. 1-1, 1993.

LASTA, C.; GAGLIARDINI, D. A.; MILOVICH, J.; ACHA, E. $\mathrm{M}$. Seasonal variation observed in surface water temperature of Samborombón Bay, Argentina, using NOAA-AVHRR and field data. J Coast. Res., v. 12, p. 18-25, 1996.

LAUBSHER, R. K., PERISSINOTO, R.; MCQUAID, C. D. Phytoplankton production and biomass at frontal zones in the Atlantic sector of the Southern Ocean. Pol. Biol., v. 13, n. 7, p. 471-481, 1993.

Le FÈVRE, J. Aspects of the biology of frontal systems. Adv. Mar. Biol., v. 23, p. 163-299, 1986.
LORENZEN, C. J. Determination of chlorophyll and phaeopigments: spectrophotometric equations. Limnol. Oceanogr., v. 12, n. 2, p. 343-346, 1967.

MACQUEEN, J. B. Some Methods for classification and Analysis of Multivariate Observations. Proceedings of $5^{\text {th }}$ Berkeley Symposium on Mathematical Statistics and Probability. Berkeley: University of California Press, 1967. p. 281-297.

MANN, K. H.; LAZIER, J. R. N. Dynamics of Marine Ecosystems. Biological Physical Interactions in the Oceans. 2nd edition. Cambridge: Blackwell, 1996. 394 p.

MANTOURA, R. F. C.; JEFFREY, S. W.; LLEWELLYN, C. A.; H. ClAUSTRE, H.; MORALES, C. E. Comparison between Spectrophotometric, fluorometric and HPLC methods for chlorophyll analysis. In: JEFFREY, S.W.; MANTOURA, S. W.; WRIGHT, S.W. (Eds.). Phytoplankton pigments in oceanography: guidelines to modern methods. Monographs on Oceanographic Methodology. Paris: SCOR, UNESCO, 1997. p. 361-380.

MIANZAN, H. M.; LASTA, C. A.; ACHA, E. M.; GUERRERO, R. A.; MACCHI, G. J.; BREMEN, C. The Río de la Plata estuary, Argentina-Uruguay. In: SEELINGER, U.; LACERDA, L. D. DE; KJERFVE, B. (Ed.). Ecological studies: coastal marine ecosystems of Latin America. Berlin: Springer-Verlag, 2001a. p. 186-204.

MIANZAN, H.W., ACHA, E. M.; GUERRERO, R. A.; RAMÍREZ, F. C.; SORARRIN, D. R.; SIMIONATO, C.; BORUS, J. South Brazilian marine fauna in the Río de la Plata estuary. Discussing the barrier hypothesis. IX Congreso Latinoamericano sobre Ciencias del Mar, San Andrés Isla, Colombia, 2001b. p. 210.

MUNK, P.; HANSEN, B. W.; NIELSEN, T. G.; THOMSEN, H. A. Changes in plankton and fish larvae communities across hydrographic fronts off West Greenland. J. Plankton. Res., v. 25 , n. 7, p. 815-830, 2003.

NAGY, G. J., LÓPEZ-LABORDE, J.; ANASTASÍA, L. Caracterización de ambientes en el Río de la Plata exterior (salinidad y turbiedad óptica). Invest. Oceanol., v. 1, n. 1, p. 31-56, 1987.

NAGY, G. J, GÓMEZ-ERACHE, M.; LÓPEZ, C. H; PERDOMO, A. C. Distribution patterns of nutrients and symptoms of eutrophication in the Río de la Plata Estuary System. Hydrobiologia, v. 475/476, n. 1, p. 125-139, 2002.

OLSON, D. B., HITCHCOK, G. L.; MARIANO, A. L.; ASHJIAN, C. J.; PENG, G.; NERO, R. W.; PODESTÁ, G. P. Life on the edge: marine life and fronts. Oceanography, v. 7, p. 52-60, 1994.

ORTEGA, L.; MARTÍNEZ, A. Multiannual and Seasonal Variability of Water Masses and Fronts Over the Uruguayan Shelf. J. Coast. Res., v. 23, n. 3, p. 618-629, 2007.

PARSONS, T. R.; TAKAHASHI, M.; HARGRAVE, B. Biological Oceanographic Processes. 2nd edition. Oxford: Pergamon Press, 1977. $332 \mathrm{p}$.

PAULY, D., CHRISTENSEN, V. Primary production required to sustain global fisheries. Nature, v. 374, p. 255-257, 1995.

PENNOCK, J. R. Chlorophyll distribution in the Delaware estuary: regulation by light-limitation. Est. Coast. Shelf Sci., v. 21, n. 5, p. 711-725, 1985.

PisciotTANO, G., DÍAZ, A.; CAZES, G.; MECHOSO, C. R. El Niño-Southern Oscillation impact on rainfall in Uruguay. J. Clim., v. 7, n. 8, p. 1286-1304, 1994. 
PIMIENTA, F. M., CAMPOS, E. J. D.; MILLER, J. L.; PIOLA, A. R. A numerical study of the Plata River plume along the southeastern South American continental shelf. Braz. J. Oceanogr., v. 53, n.3/4, p.129-146, 2005.

SHANKS, A. L.; MCCULLOCH, A. Topographically generated fronts, very nearshore oceanography, and the distribution of chlorophyll, detritus, and selected diatom and dinoflagellate taxa. Mar. Biol., v. 143, n. 5, p. 969-980, 2003.

SHANKS, A. L.; MCCULLOCH, A.; MILLER, J. Topographically generated fronts, very nearshore oceanography and the distribution of larval invertebrates and holoplankters. J. Plankton. Res., v. 25, n. 10, p. 1251-1277, 2003.
SIMIONATO, C.G., DRAGANI, W.; MECCIA, V.; NUÑEZ, M. A numerical study of the barotropic circulation of the Río de la Plata estuary: sensitivity to bathymetry, the Earth's rotation and low frequency wind variability. Est. Coast. Shelf Sci., v. 61, n. 2, p. 261-273, 2004.

SIMIONATO, C.G., VERA, C. S.; SIEGISMUND, F. Surface wind variability on seasonal and interannual scales over Río de la Plata Area. J. Coast. Res., v. 21, n. 4, p. 770-783, 2005.

STRICKLAND, J. D. H., PARSONS, T. R. A practical handbook of seawater analysis. J. Fish. Res. Bd. Canada., p. 167, 1972.

SZEKIELDA, K. H., MCGINNIS, D. Spatial Variability of River Plumes and Eutrophication. In: DEGENS, E.T.; KEMPE, S.; RICHEY, J. E. (Eds.). Biogeochemistry of major world rivers. Chistecher: Wiley and Sons, 1991. p. 1-24. 